\title{
Biology, Flowering and Fruiting of the Cactus Opuntia spp.: A Review and Some Observations on Three Varieties in Morocco
}

\author{
Mohamed Arba ${ }^{1 *}$, André Falisse ${ }^{2}$, Redouane Choukr-Allah ${ }^{1}$, Marianne Sindic ${ }^{3}$. \\ ${ }^{I}$ Hassan II Institute of Agronomy and Veterinary Medicine, Horticultural Complex of Agadir, Morocco, Ait Melloul, \\ Morocco; ${ }^{2}$ Crop Production Unit, Gembloux Agro-Bio Tech, University of Liège, Belgium; and Faculty of \\ Agriculture, University of Agricultural Sciences and Veterinary Medicine, Cluj, Romania. \\ Gembloux, Belgium; ${ }^{3}$ Gembloux Agro Bio Tech, University of Liège, Belgium, Gembloux, Belgium.
}

\begin{abstract}
The cactus is a succulent plant resistant to droughts. According to the recently reviewed classification, cacti belong to the family of Opuntiaceae Desv. (synon. Cactaceae Juss.) with Opuntia Mill. as the typical genus. This genus is economically the most important in the family, as it includes a group of cactus pear plants which play an important role in the agricultural systems of arid and semi-arid regions. Flowering of the cactus pear fruit is an important determinant of the fruit harvesting period. The goal of this paper is to present the physiology of the cactus pear and to explain in detail the biology of its flowering and fruiting processes. This study is also enriched by our observations on the flowering and fruiting of three varieties of cactus pear that we followed for two successive years in southern Morocco.
\end{abstract}

Key words: Opuntia ficus-indica, phenology, flowering, fruiting, cactus pear

\footnotetext{
*Author for correspondence: arbamohamed@yahoo.fr
} 


\section{INTRODUCTION}

The prickly pears are xerophytic plants which, according to convention-which are currently under review - belong to the new family of Opuntiaceae Desv. (synon. Cactaceae Juss.). According to the authors this family is composed of 26-160 genera and 1,500-2,000 species native to North and South America, mainly Mexico [1] and the typical genus is Opuntia Mill. [2]. The Opuntiaceae Desv. family is composed of green plants that often possess succulent stems, and are characterized by the crassulacen acid metabolism (CAM). The prickly-or cactus-pear plants are included in the genus Opuntia, and are characterized by the presence of cladodes, which are a kind of jointed stems. Their leaves are often rudimentary and transitory, or absent and replaced by spines and barbed hairs (glochids) carried by areoles (axillary nodes). Flowers are born on the upper half of the cladode until more than 25 are born; most $(90-95 \%)$ are transformed into fruits. Flowers are generally large and are born individually on the areoles. The perianth is formed by a chalice with petaloid sepals and a corolla with sepaloid petals. Stamens are numerous while the ovary is infer, containing 3-20 cyclic carpels [1].

In this family, the genus Opuntia Mill. is the most important economically as a great number of species that produce edible fruits, like as Opuntia ficus-indica (L.) Mill., O. megacantha Salm-Dyck, O. stricta Haw., O. dilennei (Ker Gawl.) Haw., O. schummannii Weber, O. robusta Wendl. and O. albicarpa Scheinvar. All species producing edible fruits are also called by the vernacular name of "prickly pear tree". Cactus pears-in particular O. ficus-indica, the true prickly pear tree-were introduced to the Mediterranean basin at the end of the $15^{\text {th }}$ century by Christopher Columbus, and then in North Africa one century later. Their distribution in the world was facilitated by the transport of fresh cladodes on European boats at the end of the $15^{\text {th }}$ century $[3,4]$. The cultivation of cactus pears extended to the hot arid regions of the world due to their resistance to drought; now, O. ficus-indica is cultivated in more than 30 countries of both hemispheres, and in all continents except the Antarctic [4,5]. Mulas et al. [6] reported that the cultivation of cactus pear can be an alternative to cereal and forage crops in arid regions of the world. There is a large variety of prickly pear cacti from their hybridisation in nature, from the creation of new varieties through clonal selection, and through the exchange of cladodes between different regions and countries [7,8]. In many countries several varieties are cultivated, most notably so in the country of origin, Mexico. The total area occupied by the cactus pear is around 3 million hectares (ha) in Mexico, including more than 70,000 cultivated ha. The area of the prickly pear cactus in Brazil, also a great producer, is 900,000 ha with 600,000 cultivated ha [9]. Inglese [10] reported around 3,000 ha for commercial production in Italy, 25,000 ha in Tunisia and more than 1,000 ha in each of the countries Chile, Argentina and South Africa. In Morocco, the area occupied by cactus pears have evolved remarkably during the last two decades, reaching around 150,000 ha and continuous to grow within the framework of the Moroccan Green Plan.

The objectives of this article are to describe some biological aspects of the prickly pear cactus, mainly the ones related to flowering and fruiting process, and to report some personal observations on the phenology of flowering and fruiting of three varieties of cactus pear in Morocco.

\section{THE BIOLOGY OF FLOWERING AND FRUITING IN CACTUS PEAR}

\section{THE PHYSIOLOGY OF PLANT}


The prickly pears are drought-resistant plants that grow perfectly in the arid regions of the globe [11]. Their success in arid environments lies in their particular CAM $[4,12]$. These plants have also developed typical morphological adaptations (transformation of leaves to spines, protection of cladodes by an impermeable cuticle) and mechanisms that allow them to use water efficiently (absorption of water when it's available and efficient storage, reduction of transpiration, etc). In the Mediterranean, the production of flowers and shoots in cactus pears occurs in the spring, when climatic conditions are favorable-i.e., when temperature and day length increase $[4,8,13]$. The threshold values can be at a temperature of $14{ }^{\circ} \mathrm{C}$ and day length of 12 hours.

Flowers are often emitted on one year old cladodes, whereas shoots are mainly emitted on two or more years old cladodes $[7,8,13]$. After the emission of floral buds, flowering takes place for about one month and is followed by the development of fruits. The plant is able to flower a second time during the same year if the environmental conditions are favorable (i.e. clement temperatures, frequent fogs or high hygrometry of the air) or through the use of advanced agriculture techniques (i.e. continuous irrigation and fertilization programs, or irrigation during the dry summer period $[4,7,13,14]$. This phenomenon is called "reflowering" and it presents a non-negligible interest to the farmers, with the timing of the production period and potential for reflowering and total annual production having large impacts on the income of farmers. Cactus pears need an average temperature of more than $10^{\circ} \mathrm{C}$, a mild winter and a hot summer $[4,10]$. The plant starts producing fruits $2-3$ years after plantation. Full production is obtained approximately 7 years after plantation, and fruit production can last $25-30$ years or longer [7,8,13]. Fruit yields vary from 1-5 tons ( $\mathrm{t}$ ) per ha in traditional plantations and can reach $15-50 \mathrm{t} / \mathrm{ha}$ in modern plantations [5,10]. Mulas et al. [6] reported that fruit yield of 22 accessions in the Chaouia-Ouardigha central region of Morocco is medium or high (yield was not specified).

\section{BIOLOGY OF FLOWERING}

Flowers are sessile, large, often solitary and typically born on the upper part of the cladode. They are regular, composed of several sepals, yellow petals, and stamens, and only have a single pistil with a lobbed stigma at the apex. The stamens and pistil are often yellow or green. The average number of petals is 19 for $O$. phaeacantha Engelm. and 11 for $O$. ficus-indica, and they possess 258 and 240 stamens, respectively $[7,13]$. The ovary-located under the floral parts-is consisting of several fused carpels and numerous ovules with parietal placentation $[4,7,8,13]$. The number of ovules per ovary varies from 150-400 for O. ficus-indica and O. robusta Wendland, and that of the number of pollen grains per flower is about 160,000 [7,13].

In the Mediterranean basin, flowers begin to open in the spring; it is followed by the development of fruits, which reach maturity during the summer period $[7,8,13]$. Mulas [15] reported that the period of development of floral buds at 'Gialla' variety under natural conditions of Sardinia is located between April and July. Flowers of the prickly pears are commonly diurnal and anthesis begins early in the morning after sunrise. They typically remain open between $8-11$ a.m. [7,13,14], but some flowers can remain open until the next day [7,13]. Full flowering occurs around midday, after which the perianth starts to close gradually until it is completely closed by the end of the day $[7,8,13,14]$. Floral bud emission of $O$. ficus-indica lasts 3-5 weeks $[13,16]$ and two months in Selviria, Brazil [14]. However, this period can exceed 25 weeks in some species $[13,16]$. The timeframe which separates the floral 
bud development period and the opening of flowers is relatively short in the prickly pears, lasting only $30-50$ days $[13,14]$ while the development of floral buds alone, from their emission until anthesis, varies from $7-10$ weeks in other species $[8,13,16]$. Flowering extends over a period of 48 days [14] to 100 days [7,8,13,15,17], with the peak of flowering corresponding to the period when 50\% of flowers are open [14]. Cactus pear flowering is not synchronous: the phenologic phases overlap, with the start of floral bud formation starting well before the end of the emission of both vegetative and floral buds, and the maturation of fruits can also start little before the end of flowering $[7,13,14]$. As a consequence, the phases of flowering and fruit maturation are spread out over a period of several weeks $[7,8,15]$.

Many authors define the phase of flowering as the period which extends from the beginning of flowering (5\% of open flowers) until the end of flowering [7,18]. Barbara [19] determined the duration of a phenologic phase of flowering or fruiting as the period between week when the first characteristics of each phase are visible on a specific variety of cactus (i.e. open flowers), until the last week they are visible on the same variety.

\section{POLLINATION AND FRUITING}

Hermaphrodite flowers are the most frequent on cactus pears [3,7], but crosspollination occurs most often $[7,13]$. Bees are the major pollinators of the prickly pears. Factors favoring this pollination are the auto-incompatibility, the dichogamy (male and female organs do not mature at a same time in a flower), the herchogamy (separation in space between anthers and stigma) and the unisexuality of prickly pears. A stigma receives several grains of pollen but only about $30 \%$ of these grains germinate on the style. The germination of pollen grains and the development of pollen tubes in the style are made relatively quickly, within 24-48 hours [13]. Very few flowers fail to form fruits, as $95 \%$ of formed cactus pear flowers can yield fruits $[7,13]$, whereas fruit-bearing species like apple, avocado, mango and orange trees often have less than $10 \%$ of flowers transforming into fruits [13]. This could be partially due to the cactus pears water reservation techniques, where the reproductive organs can access stored reserves during the dry period [12].

\section{THE FRUIT DEVELOPMENT PERIOD (FDP)}

The FDP is defined as the period of time between the formation of floral buds (or reproductive bud break) and the maturation of fruits (or 50\% of fruit ripening) [8]. Floral buds are formed when they reach a length of $4-5 \mathrm{~mm}$; at this stage they become spherical and easy to distinguish from vegetative buds, which are puntshaped. This is also the stage where the first signs of flower structure can be detected under a microscope $[7,8,13,19]$.

There is a large variability in the FDP, which appears to be variety-specific [8,19]; it also varies between regions, as it depends on the climatic conditions of the cultivation medium $[8,14]$. The FDP for the majority of varieties studied in South Africa is 120-130 days; for plants which have an earlier emission of floral buds, the FDP is longer and can reach up to 148 days [8]. Other authors report the emission of floral buds varying from 96-122 days, with the maturation of fruit varying from 66 days, or 80-90 days after flowering $[8,14]$.

\section{THE PHENOLOGY OF FLOWERING AND FRUITING OF THREE VARIETIES IN MOROCCO}

The primary objective of this study was to follow the phenology of three varieties of Opuntia in the Agadir area: the spineless varieties "Aissa" and "Moussa" of O. ficusindica, and the thorny variety "Achefri" of $O$. megacantha. In addition, we wanted to see whether the physiological stages and the phenological phases of the three 
varieties, mainly the phases of flowering and fruiting, occur at similar times, and to compare the period of these phases with those observed in other regions.

\section{MATERIAL AND METHODS}

To study the flowering and fruiting phenology of the cactus pear in Morocco, we followed the flowering and fruiting of three varieties for two successive years (2011-2012; Table 1). For each variety, we followed a sample of 10 one year old cladodes in each of the 4 rows of the plantation, and in 4 randomized plots considered as blocks of the repetitions. We adopted the method of Barbara [19] to determine the period of both the flowering and fruiting phases. We have chosen the method of Barbara [19] than other methods: Reyes-Aguero et al. [7], Chessa and Nieddu [18], because in the first one the FDP starts at the formation of floral buds, when fruit development is beginning in cactus pear because this development starts well before the formation of floral parts. However, the real start and end dates may differ from our observed sample dates, and this was indicated in the records.

Table 1: Observations realized during the two years of observations on the phenology of flowering and fruiting of 'Achefri', 'Aissa' and 'Moussa' in the Agadir area.

\begin{tabular}{|c|c|c|c|}
\hline \multirow[b]{2}{*}{ Phenologic phase } & \multicolumn{3}{|c|}{ Realized observations } \\
\hline & 2011 & & 2012 \\
\hline \multirow{2}{*}{$\begin{array}{l}\text { Emission of vegetative and } \\
\text { floral buds and formation of } \\
\text { floral buds }\end{array}$} & obse & observations & observations \\
\hline & $\begin{array}{l}(03 / 03 ; \quad 11 / 03 ; \\
29 / 03 ; \quad 05 / 04 \\
10 / 05 ; 25 / 05)\end{array}$ & $\begin{array}{l}21 / 03 \\
20 / 04\end{array}$ & $\begin{array}{l}(02 / 02 ; 17 / 02 ; 01 / 03 ; 15 / 03 \\
27 / 03 ; 11 / 04 ; 24 / 04\end{array}$ \\
\hline \multirow[t]{2}{*}{ Flowering } & & observations & observations \\
\hline & $\begin{array}{l}(03 / 03 ; \quad 11 / 03 \\
29 / 03 ; \quad 05 / 04 \\
10 / 05 ; 25 / 05)\end{array}$ & $\begin{array}{l}21 / 03 \\
20 / 04\end{array}$ & $\begin{array}{l}(27 / 03 ; 11 / 04 ; 24 / 04 ; 09 / 05 \\
23 / 05 ; 10 / 06)\end{array}$ \\
\hline \multirow[t]{2}{*}{ Fruiting } & & observations & $7 \quad$ observations \\
\hline & $\begin{array}{l}(18 / 06 ; \quad 28 / 06 \\
20 / 07 ; \quad 31 / 07 \\
01 / 09 ; 15 / 09)\end{array}$ & $\begin{array}{l}12 / 07 \\
15 / 08\end{array}$ & $\begin{array}{l}(22 / 06 ; 04 / 07 ; 17 / 07 ; 01 / 08 \\
09 / 08 ; 17 / 08 ; 27 / 08\end{array}$ \\
\hline
\end{tabular}

\section{RESULTS AND DISCUSSION}

\section{Vegetative and floral bud emission}

Monitoring the flowering and fruiting phases made it possible to note that emission of vegetative and floral buds, and flowering of these varieties were important from March-May, the timeframe when temperatures were clement and day length increased (Table 2, 3). This is in agreement with findings on the cactus pears from the northern hemisphere $[4,7,8,13]$. During the first year of observations, the phase of the emission of vegetative and floral buds was 89 days long for spineless varieties and 76 days long for the thorny variety. The duration of the bud emission phase exceeded what was reported by others by $21-60$ days $[13,14,16]$, but was shorter than the period indicated for $O$. joconostle Weber [16]. The period of time which separated the end of floral bud emission and the beginning of flowering varied from one variety to another, lasting 15-23 days in 2011 but 55-63 days in 2012.

Table 2: Duration of the phenologic phases of flowering and fruiting of 'Achefri', 'Aissa' and 'Moussa' during the first year of observations (2011) in the Agadir area.

\begin{tabular}{|c|c|c|c|c|c|}
\hline & Phenologic phase & & & & \\
\hline & Emission of & Formation & Flowering & Fruit & FDP \\
\hline
\end{tabular}




\begin{tabular}{|c|c|c|c|c|c|}
\hline $\begin{array}{l}\text { Varie } \\
\text { ty }\end{array}$ & $\begin{array}{l}\text { vegetative and } \\
\text { floral buds }\end{array}$ & floral buds & & maturation & \\
\hline Aissa & $\begin{array}{l}89 \text { days } \pm 4: \\
18 \text { Feb-18 May }\end{array}$ & $\begin{array}{l}90 \text { days } \pm 5: \\
24 \text { Feb-25 May }\end{array}$ & $\begin{array}{l}89 \text { days } \pm 7: \\
3 \text { Mar }-1 \text { June }\end{array}$ & $\begin{array}{l}79 \text { days } \pm 6: \\
28 \quad \text { June }-15 \\
\text { Sept }\end{array}$ & $\begin{array}{l}145 \text { days } \pm 6: \\
24 \quad \text { Feb }-20 \\
\text { July }\end{array}$ \\
\hline $\begin{array}{l}\text { Mous } \\
\text { sa }\end{array}$ & $\begin{array}{l}89 \text { days } \pm 4: \\
18 \text { Feb-18 May }\end{array}$ & $\begin{array}{l}90 \text { days } \pm 5: \\
24 \text { Feb-25 May }\end{array}$ & $\begin{array}{l}81 \text { days } \pm 7: \\
11 \text { Mar-1 June }\end{array}$ & $\begin{array}{l}72 \text { days } \pm 4: \\
28 \quad \text { June }-8 \\
\text { Sept }\end{array}$ & $\begin{array}{l}156 \text { days } \pm 5: \\
24 \quad \text { Feb }-31 \\
\text { July }\end{array}$ \\
\hline $\begin{array}{l}\text { Achef } \\
\text { ri }\end{array}$ & $\begin{array}{l}76 \text { days } \pm 4: \\
3 \text { Mar }-18 \text { May }\end{array}$ & $\begin{array}{l}76 \text { days } \pm 4: \\
3 \text { Mar-18 May }\end{array}$ & $\begin{array}{l}65 \text { days } \pm 7: \\
21 \text { Mar }-25 \text { May }\end{array}$ & $\begin{array}{l}63 \text { days } \pm 4: \\
7 \text { July }-8 \text { Sept }\end{array}$ & $\begin{array}{l}164 \text { days } \pm 5: \\
3 \text { Mar-15 Aug }\end{array}$ \\
\hline
\end{tabular}

Table 3: Duration of the phenologic phases of flowering and fruiting of 'Achefri', 'Aissa' and 'Moussa' during the second year of observations (2012) in the Agadir area.

\begin{tabular}{|c|c|c|c|c|c|}
\hline \multirow[b]{2}{*}{ Variety } & \multicolumn{5}{|c|}{ Phenologic phase } \\
\hline & $\begin{array}{l}\text { Emission of } \\
\text { vegetative } \\
\text { and floral } \\
\text { buds }\end{array}$ & $\begin{array}{l}\text { Formation of } \\
\text { floral buds }\end{array}$ & Flowering & $\begin{array}{l}\text { Fruit } \\
\text { maturation }\end{array}$ & FDP \\
\hline Aissa & $\begin{array}{l}98 \text { days } \pm 5: \\
24 \quad \text { Jan }-2 \\
\text { May }\end{array}$ & $\begin{array}{l}98 \text { days } \pm 4: \\
2 \text { Feb-9 May }\end{array}$ & $\begin{array}{l}85 \text { days } \pm 4: \\
27 \text { Mar-20 June }\end{array}$ & $\begin{array}{l}76 \text { days } \pm 6: \\
22 \quad \text { June }-6 \\
\text { Sept }\end{array}$ & $\begin{array}{l}180 \text { days } \pm 3: \\
2 \text { Feb-1 Aug }\end{array}$ \\
\hline Moussa & $\begin{array}{l}76 \text { days } \pm 7: \\
2 \quad \text { Feb }-17 \\
\text { Apr }\end{array}$ & $\begin{array}{l}83 \text { days } \pm 5: \\
2 \text { Feb-24 Apr }\end{array}$ & $\begin{array}{l}78 \text { days } \pm 3: \\
27 \text { Mar-13 June }\end{array}$ & $\begin{array}{l}\text { 84 days } \pm 5: \\
14 \quad \text { June }-6 \\
\text { Sept }\end{array}$ & $\begin{array}{l}180 \text { days } \pm 3: \\
2 \text { Feb-1 Aug }\end{array}$ \\
\hline Achefri & $\begin{array}{l}76 \text { days } \pm 7: \\
2 \quad \text { Feb-17 } \\
\text { Apr }\end{array}$ & $\begin{array}{l}76 \text { days } \pm 6: \\
10 \quad \text { Feb }-24 \\
\text { Apr }\end{array}$ & $\begin{array}{l}70 \text { days } \pm 6: \\
27 \text { Mar }-6 \text { June }\end{array}$ & $\begin{array}{l}61 \text { days } \pm 5: \\
22 \quad \text { June }-22 \\
\text { Aug }\end{array}$ & $\begin{array}{l}172 \text { days } \pm 3 \text { : } \\
10 \text { Feb-1 } \\
\text { Aug }\end{array}$ \\
\hline
\end{tabular}

During the second year of observations, the period of vegetative and floral bud emission, and flowering, were earlier compared to 2011 (Fig. 1). This was probably due to differences in climatic conditions, which were characterized by low rainfall from March-April and high temperatures from February-March in 2012 (Fig. 2). The emission of vegetative and floral buds began one month before the date of this emission in the first year; it started early in February (Fig. 1). The duration of the emission period was 76-98 days long for the three varieties (Table 3). In another trial taking place in the same area, the duration of the vegetative and floral bud emission phase for 'Moussa' was 98 days long in 2011 and 80 days in 2012.

Over the two years of observation, the duration of vegetative and floral bud emission, along with floral bud formation, was 76-98 days long (Table 2, 3). 


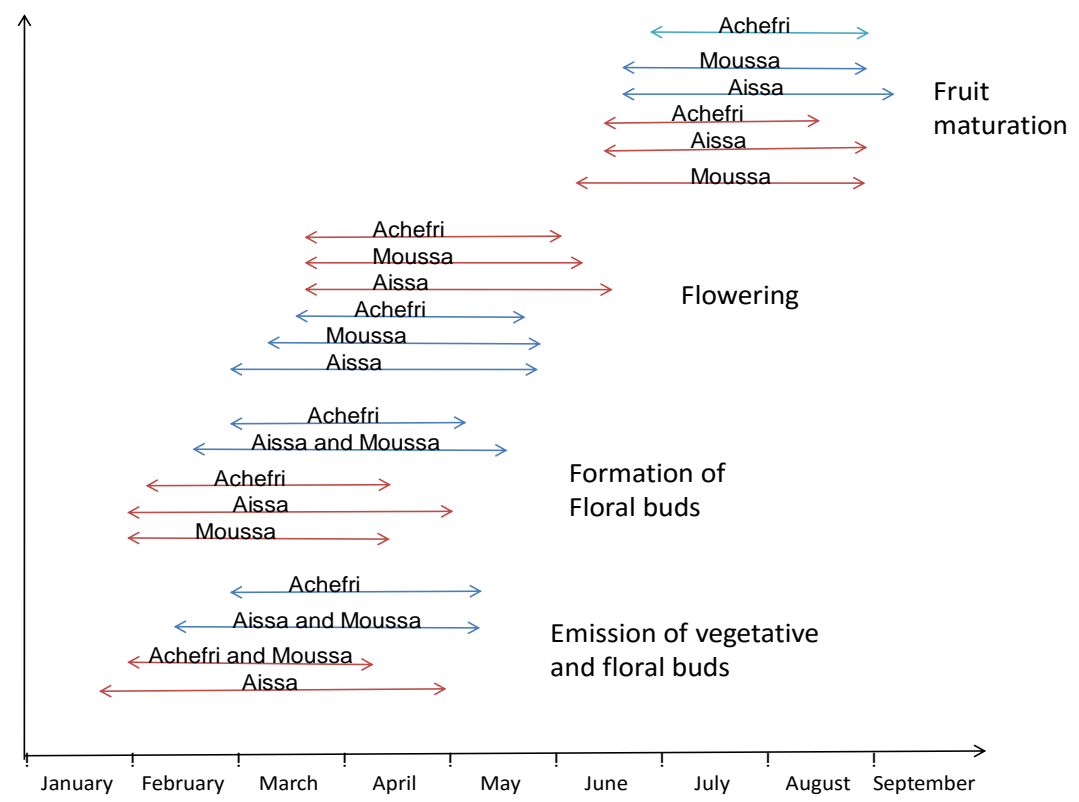

Legend: $\longleftrightarrow$ First year of observations Second year of observations

Figure 1: Phenologic phases of flowering and fruiting of 'Achefri', 'Aissa' and 'Moussa' during the two years of observations in the Agadir area

\section{The phases of flowering and fruiting}

In the first year of observations, the phase of flowering was longer (78-85 days) and later for the spineless varieties 'Aissa' and 'Moussa' than for the 'Achefri', and fruit maturation also occurred later for the spineless varieties compared to the 'Achefri' (Fig. 1). During the second year of observations, the period of flowering was 65 days for 'Achefri', 81 days for Moussa, and 89 days for 'Aissa'. Similar periods-ranging from two months to 100 days - are reported by other authors in some countries (Brazil, Italy, Mexico, South Africa) $[8,13,14,15,17]$. The period of fruit maturation is also little longer for 'Aissa' (79 days) and shorter at 'Achefri' (63 days). In another trial taking place in the same area, the flowering phase was 80 days in 2011 and 66 days in 2012 [20]. In the central zone of the country, the period of flowering of two varieties in Khouribga area (the spineless 'Mles' of $O$. ficus-indica and the thorny 'Draibina' of $O$. megacantha) was about 50 days long and extended from April 9th to May 29th [21]. In the same central zone, the ripening time of 22 accessions in the Chaouia-Ouardigha region could be early, late or medium-late [6]. This is an example of the phenological diversity between Opuntia varieties during different years and regions, as a result of genetic diversity and annual climatic conditions. Those, over the two years of our observations, there are differences between the duration of the phase of flowering and between varieties. The flowering phase is 6570 days long for 'Achefri', 78-85 days long for 'Moussa', and 85-89 for 'Aissa'.

The period which separates the end of flower opening and the beginning of fruit maturation was 27-43 days long in 2011 and 1-16 days in 2012 (Table 2, 3). These periods were much shorter than previous reports of different Opuntia varieties, where the range was between $40-60$ days $[7,8,14]$. The fruit maturation period of the three varieties during 2011 extended from the end of June to mid-September (Fig. 1). It was 63 days long for 'Achefri' (it extend from July $7^{\text {th }}$ to September $8^{\text {th }}$ ); 72 days 
for 'Moussa' (it's located between June 28th and September 8th) and 79 days for 'Aissa' (from June 28th to September 15th) (Table 2). In 2012 (Table 3), the period of maturation was 61 days long for 'Achefri' (from July 7th to September 8th), 84 days for 'Moussa' (from June 14th to September 6th); and 76 days for 'Aissa' (from June 22nd to September 6th). The end of the fruit maturation period for all three varieties occurred between the $6^{\text {th }}$ and the $15^{\text {th }}$ of September for both years, but the end of harvest of an amount of fruits which can be the object of marketing is located around the beginning of September. What represents a non-negligible lateness of about 15 days in the harvesting period in comparison to the end of the prickly pears season of production in Morocco which is located at mid-August; this provides evidence supporting the notion that different times are required for fruit maturation in different Opuntia species, which also varies between regions. For example, it extends from 80 days in Brazil [14] to several weeks in other countries [8]. In addition, Valdez-Cepeda et al. [22] showed that, even within a variety, variation in environmental conditions also affects the time required for fruit maturation.

The duration of the majority of the flowering and fruiting phases for the three varieties was shorter in the second year due to differences in the climatic conditions between both years. The second year was marked by low rainfall during spring $(0$ $\mathrm{mm}$ in March, $4.2 \mathrm{~mm}$ in April and $0.6 \mathrm{~mm}$ in May against 67.6; 65.6 and $137.8 \mathrm{~mm}$ in the 2011, respectively), low amounts of sunlight during the winter (about 439,000 $\mathrm{kWh} / \mathrm{m}^{2}$ in January 2012 and 518,000 $\mathrm{kWh} / \mathrm{m}^{2}$ in February, 2012 against 473,000 and $546,000 \mathrm{kWh} / \mathrm{m}^{2}$ in January and February of 2011, respectively) and colder winters $\left(12.8^{\circ} \mathrm{C}\right.$ in January and $12.5^{\circ} \mathrm{C}$ in February against 13.9 and $13.2^{\circ} \mathrm{C}$ for 2011 , respectively)

\section{The FDP}

The FDP also varies between varieties [8,19], regions - as a result of different environmental conditions $[8,14]$ - and years. During the first year of observations, it was 156 days long for 'Moussa', 145 days for 'Aissa', and 164 days for 'Achefri'. During the second year, the FDP was longer - taking 180 days for spineless varieties and 172 days for the 'Achefri'. The FDP was lengthier in 2011 (Fig. 1), possibly due to the amount of rainfall in December (124 mm vs $99.4 \mathrm{~mm}$ for the first and second year, respectively) and January (47.2 vs $151.4 \mathrm{~mm}$; Fig. 2). Arba et al. [20], who also recorded the 'Moussa's FDP in the same area noted that it lasted 152 days in 2011, and 188 days in 2012. However, Barbara [19] has noted that varieties which have an early emission of floral buds have a longer FDP, which is in line with what is reported here. This last author reported that for two seasons, the FDP of the majority of varieties in South Africa varied between 120-130 days, and that the FDP of varieties with longer FDP varies from 148 days during the first year to 162 days or more during the second year. Comparatively, the FDP of $O$. ficus-indica is for 96 days in Brazil [14] and about 122 days in Italy [8]. 


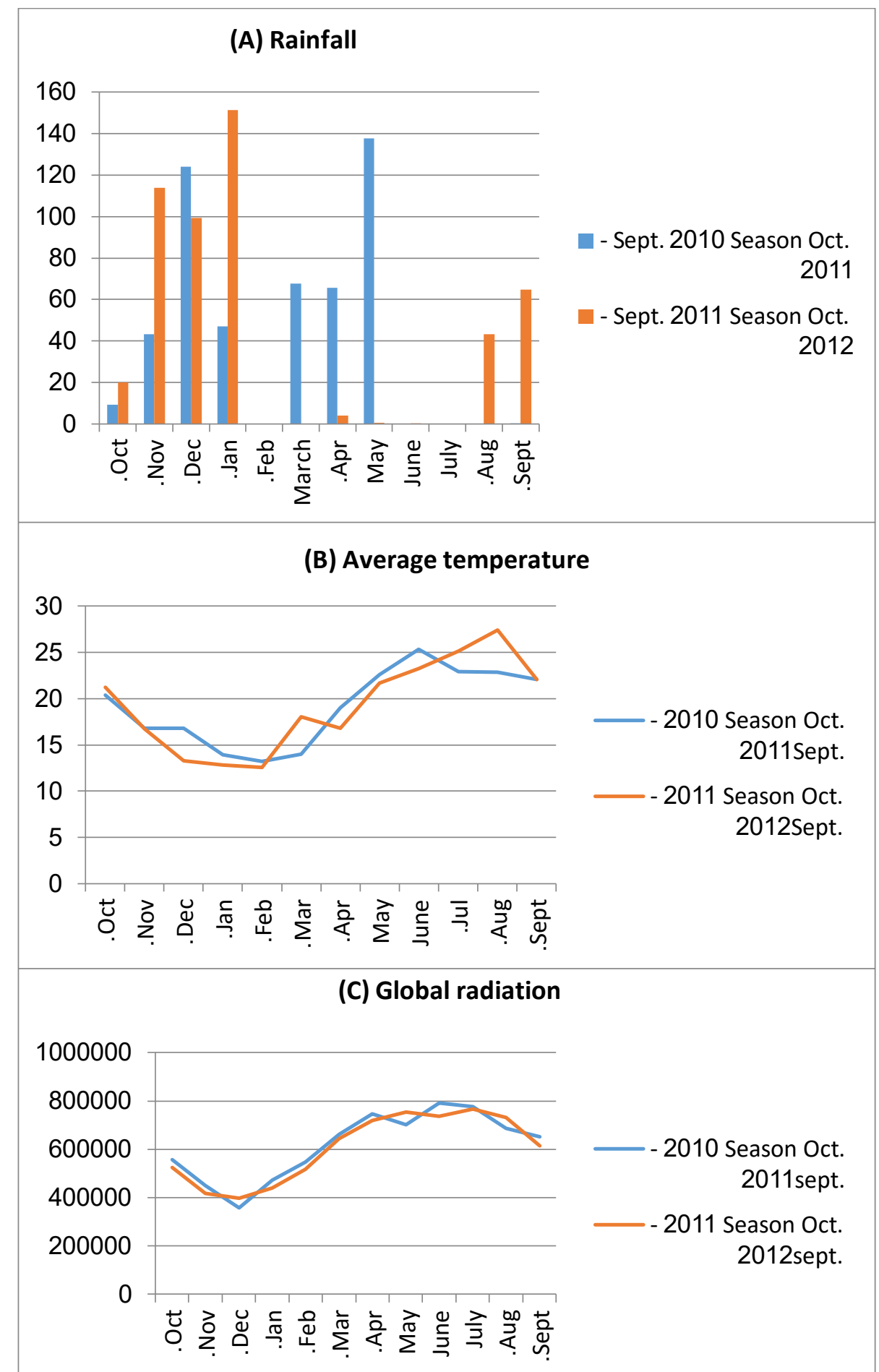

Figure 2: Climatic data of the experimental area during the two years of observations: (A): Rainfall; (B): Average temperature; and (C): Monthly sum of global radiation.

\section{CONCLUSIONS}

The periods of the emission of vegetative and floral buds, and flowering, typically occur in the spring but can be little earlier or later depending on the variety, the region of cultivation and climatic conditions of that year. Our observations on three 
varieties showed a diverse phenology of flowering and fruiting for the cactus pear, with the period between March and May being the most important for the emission of vegetative and floral buds and the flowering. In addition, our observations on the phenological phases of the cactus pear also reflect a trend that is observed in other plants: phases can overlap, with flowering, fruit development and maturation occurring simultaneously.

The duration of the majority of the flowering and fruiting phases for the three varieties was shorter in the second year, and occurred later; these results were likely due to differences in the climatic conditions between both years. Our second year of observations was marked by low rainfall during spring and low amounts of sunlight during the winter. Climatic conditions of 2012 were also marked by colder winters and involved an early initiation of floral buds. The FDP varies between varieties and years, but was longer for the three varieties in the second year compared to the first, thanks to earlier floral bud formation. This observation is supported by several authors, who also reported that the FDP varies from one variety to another and from one year to another $[8,14,19]$.

The end period of fruit maturation for the three varieties over the two years was between the $6^{\text {th }}$ and the $15^{\text {th }}$ of September and the end period of harvest of an amount of fruits which can be marketed is situated around the end of August until the beginning of September which is close to the end of the Moroccan prickly pear harvesting period, making it an excellent time for marketing this fruit

Studies on the phenology of flowering and fruiting of cactus pear in the world are not numerous and investigations are underway that will provide an explanation on differences in the behavior between varieties in regard to their fruit production.

\section{ACKNOWLEDGEMENTS}

The authors wish to thank the Belgian Technical Cooperation (BTC) and Agrotech Souss Massa Draa for their financial support, and to all the people who contributed to the realisation of this study.

\section{REFERENCES}

1. Anon. Field botany at Williams College. Ed. Williams College. USA; 2006.

2. GRIN. Opuntiaceae information from NPGS (National plant germplasm system) of GRIN (Germplasm resources information network). Taxonomic information on cultivated plants in the USA. National genetic resources program. United States Department of Agriculture, Agricultural research service. Maryland, USA; 2007.

3. Anderson EF. The cactus Family. Timber Press. Oregon, USA; 2001.

4. FAO. Agro-industrial utilization of cactus pear. Rural Infrastructure and Agro Industrial Division. FAO, Rome; 2013.

5. Inglese P, Basile F, Schirra M. Cactus pear fruit production. In: Nobel PS editor. Cacti: Biology and uses. University of California Press; 2002. p. 163-183.

6. Mulas M, Loi M, El Mzouri EH, Chiriyaa A, El Gharous M, Aouragh EH, Arif A, Mazhar M. Cactus pear (Opuntia ficus-indica Mill.) genetic resources from central regions of Morocco. Agr. Med. 2006; 136: 11-19.

7. Reyes-Aguero JA, Aguirre JR, Valiente-Banuet A. Reproductive biology of Opuntia: A review. J Arid Environ. 2006; 64: 549-585.

8. Nerd A, Mizrahi Y. Reproductive biology of cactus fruit crops. Hort Rev. 2010; 18: 321-346.

9. Santo-Ares T, Venusa de Silva M, Alves de Almeido CM, Oliveira D. Genetic diversity in cactus clones using ISSR Markers. Acta Hort. 2009; 811: 55-65.

10. Inglese P. Cactus pear Opuntia ficus-indica (L.) Mill. for fruit production: An overview. FAO Cactusnet Newsletter special issue; 2010. 
Biology, Flowering and Fruiting of Opuntia

11. Patel S. Reviewing the prospects of Opuntia pears as low cost functional foods. Rev Env Sci Biot. 2013; 12(3): 223-234.

12. Nobel PS. Cacti: Biology and uses. University of California Press; 2002.

13. Pimienta-Barrios E, Del Castillo RF. Reproductive Biology. In: Nobel PS editor. Cacti: Biology and uses. University of California Press; 2002. p. 75-90.

14. Segantini DM, Torres LA, Boliani AC, Leonel S. Phenology of cactus pear in SelviriaMS State, Brazil. Rev Bras Frutic. 2010; 32(2): 630-636.

15. Mulas M. Blossoming and fructification cycle of Opuntia ficvus-indica Mill. in the Mediterranean environment. Acts of the 2nd International Congress on cactus pear and cochineal. Santiago, Chile; 1992. p. 53-60.

16. Reyes-Aguero JA, Aguire JR, Rodriguez-Flores JL. Variación morfológica de Opuntia (cactaceae) en relación con su domesticación en la altiplanicie meridional de México. Interciencia. 2005; 30(8): 476-484.

17. Lenz M, Orth AI. Mixed reproduction systems in Opuntia monacantha (Cactaceae) in Southern Brazil. Braz J Bot. 2012; 35(2): 49-58.

18. Chessa I, Nieddu G. Descriptors for cactus pear (Opuntia spp.). FAO Cactusnet Newsletter special issue. Tipografia moderna. Sassari, Italy; 1997.

19. Barbara KM. Characterization of cactus pear germplasm in South Africa. A thesis of Philosophiae Doctor. Faculty of Natural and Agricultural Sciences, University of the Free State, South Africa; 2007.

20. Arba M, Falisse A, Choukr-Allah R, Paul R. Phenology of flowering and fruiting of cactus pear and effect of NP fertilizing. Acta Hort. 2015; 1067: 31-38.

21. Arba M, Sharoua E. 'Mles' and 'Draibina' wild populations of cactus pear in Khouribga area. Acta Hort. 2013; 995: 63-68.

22. Valdez-Cepeda RD, Blanco-Macias F, Magallanes-Quintanar R, Vasquez-Alvarado R, Mendez-Gallegos de Jesus S. Fruit weight and number of fruits per cladode depend on fruiting cladode fresh and dry weight in Opuntia ficus-indica (L.) Mill. variety. Sci Hortic. 2013; 161: 165-169. 